\title{
A New Zn II Tweezer Pyridine-Naphthalene System - An Off-On-Off System Working in a Biological pH Window
}

\author{
Ricardo Aucejo, ${ }^{[a]}$ Javier Alarcón, ${ }^{[a]}$ Enrique García-España, ${ }^{*[a]}$ José M. Llinares, ${ }^{[b]}$ \\ Katherine L. Marchin, ${ }^{[a]}$ Conxa Soriano, ${ }^{[b]}$ Carlos Lodeiro, ${ }^{[c]}$ M. Alexandra Bernardo, ${ }^{[c, d]}$ \\ Fernando Pina, ${ }^{*[c]}$ João Pina, ${ }^{[\mathrm{el}]}$ and J. Seixas de Melo ${ }^{[\mathrm{el}}$
}

Keywords: Luminescence / N ligands / Sensors / Zinc

The synthesis, protonation behaviour and $\mathrm{Zn}^{2+}$ coordination chemistry of a new photoactive polyamine exhibiting "offon-off" fluorescence is presented. Addition of $\mathrm{Zn}^{2+}$ reduces the width of the fluorescence window, which is centred around physiological $\mathrm{pH}$, and sharply enhances the emission intensity.

(๔ Wiley-VCH Verlag GmbH \& Co. KGaA, 69451 Weinheim, Germany, 2005)

\section{Introduction}

The concept of $\mathrm{pH}$ windows leading to "off-on-off" fluorescence was discussed by A. P. de Silva and co-workers a few years ago. ${ }^{[1]}$ Their basic idea consisted of the connection of an amine to a fluorophoric anthracene unit on one side and to a pyridine moiety on the other. At acidic $\mathrm{pH}$ values the amino and the pyridine groups are protonated and a photoinduced electron transfer (PET) occurs from the $\pi-\pi^{*}$ excited state of the anthracene to the protonated pyridinium unit, leading to quenching of the fluorescence. However, at high $\mathrm{pH}$ values, where the amino group is not protonated, PET alternatively takes place from the amine lone pair to the same excited state of the fluorophore, yielding the same inhibitory effect on the fluorescence. Between these two $\mathrm{pH}$ values, there is a $\mathrm{pH}$ window where PET does not take place and fluorescence emission is observed. Based on this idea, A. P. de Silva et al. have developed several related "off-on-off" fluorescent systems combining anthracene, pyridine and amino groups. ${ }^{[2,3]}$ On the same lines,

[a] Departament de Química Inorgànica, Facultat de Química, Universitat de València,

Burjassot, Spain

Fax: +34-96-354-4879

E-mail: Enrique.Garcia-es@uv.es

[b] Departament de Química Orgánica, Facultat de Farmacia, Universitat de València, Burjassot, Spain

[c] REQUIMTE, Departamento de Química, Faculdade de Ciências e Tecnologia, Universidade Nova de Lisboa,

Lisboa, Portugal

Fax: +351-21-294-8550

E-mail: fjp@dq.fct.unl.pt

[d] Instituto Superior de Ciências da Saúde-Sul, Cooperativa de Ensino Superior Egas Moniz, Campus Universitário, Quinta da Granja, 2829-511 Monte de Caparica, Portugal

[e] Departamento de Química, Universidade de Coimbra, 3004-535 Coimbra, Portugal

$\square$ Supporting information for this article is available on the WWW under http://www.eurjic.org or from the author.
S. A. de Silva et al. have reported a system containing two pyridine units and one anthracene fluorophore, all of them connected to a tertiary nitrogen through methylenic groups, that is able to display on-off-on behaviour in the presence of $\mathrm{Zn}^{2+}$ in methanol/water. ${ }^{[4]}$ Fabbrizzi et al. ${ }^{[5]}$ have also reported a related tweezer that has anthracene and a twoamine, two-pyridine system which displays off-on-off fluorescent behaviour in water/acetonitrile both when free and when coordinated to $\mathrm{Zn}^{2+}$. More recently, S. A. de Silva has shown the influence of sodium and protons on the on-offon behaviour of a system built up by a 15 -membered crown ether, anthracene and anabasine in methanol. The on state is only achieved when the system is monoprotonated in the presence of $\mathrm{Na}^{+}{ }^{[6]}$

In this paper, we present a tweezer system that works in water and exhibits an optimised $\mathrm{pH}$ window. With this purpose, we have prepared a compound consisting of a triamine chain functionalised at both of its termini with 4picolyl units and at its central nitrogen with a methylnaphthyl fragment (L, Scheme 1). The binding of metal ions like

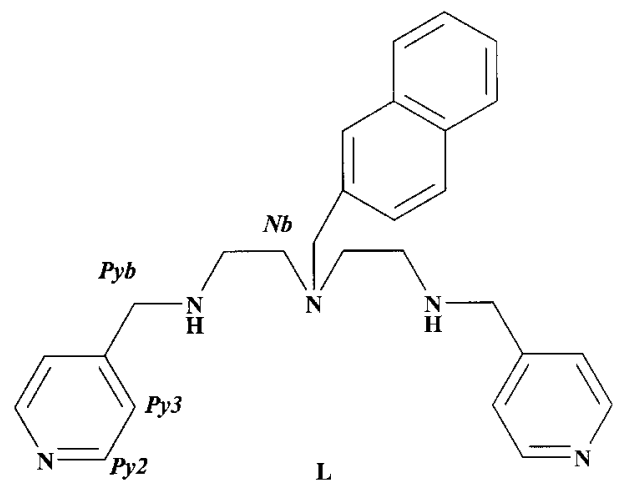

Scheme 1. Drawing of the ligands relevant to the discussion of this work. $\mathrm{L}$ is studied here. 
$\mathrm{Zn}^{2+}$ to the polyamine chain can give rise to metal complexes that are able to present fluorescence $\mathrm{pH}$ windows with improved "off-on-off" performance and a narrower $\mathrm{pH}$ range. In addition, $\mathrm{Zn}^{2+}$ is a very interesting metal ion from a biochemical point of view due to its presence in the active site of many hydrolytic enzymes and its involvement in processes that take place in the central nervous system. ${ }^{[7-13]}$ Thus, the ability to sense $\mathrm{Zn}^{2+}$ at physiological $\mathrm{pH}$ is an attractive goal. As the characteristics of the system reported here make it a promising candidate in this respect, we have explored this possibility.

\section{Results and Discussion}

\section{Synthesis}

$\mathrm{L}$ was synthesised in a four-step procedure (Scheme 2) that includes: i) protection of $N^{1}$-(2-aminoethyl)ethane-1,2diamine with phthalate groups to avoid the alkylation of the secondary amino groups, ${ }^{[14]}$ ii) alkylation of the central nitrogen by nucleophilic attack with (bromomethyl)naphthalene, ${ }^{[12-16]}$ iii) deprotection of the phthalate groups with hydrazine in ethanol to give the free alkylated polyamine, which precipitated as its hydrochloride salt, and iv) condensation of the polyamine with 4-pyridinecarbaldehyde in a 1:2 ratio to obtain the imine of $\mathrm{L}$, which was reduced in situ with $\mathrm{NaBH}_{4}$. Finally, L was precipitated as its hydrochloride salt by addition of aqueous $\mathrm{HCl}$ to an ethanolic solution of $\mathrm{L}$.

\section{Protonation Behaviour}

The protonation constants of tweezer $\mathrm{L}$ at $298.1 \pm 0.1 \mathrm{~K}$ in $0.15 \mathrm{M} \mathrm{NaCl}$ by $\mathrm{pH}$-metric titration, determined using the program HYPERQUAD, ${ }^{[17]}$ are shown in Table 1. There are several points of interest to be noted. First, the number of protonation constants found (five) indicates that all the protonable groups in the compound undergo protonation in the $\mathrm{pH}$ range of study. As discussed below, the first two protonation processes, which mainly affect the secondary amino groups, are rather low in comparison with saturated triamines like 1,4,7-triazaheptane (dien) ${ }^{[18]}$ or with respect to analogous polyamines functionalised with benzene rings at both of their termini instead of pyridine. ${ }^{[19]}$ This detrimental effect on the basicity can be ascribed to the electron-withdrawing characteristics of pyridine, which cause the adjacent nitrogen atoms to be less negatively charged. On the other hand, it is well-known that tertiary nitrogen atoms are less basic in water than secondary ones due to solvation effects. ${ }^{[20]}$ Therefore, the presence of the methylnaphthyl group at the central nitrogen also contributes to the low overall basicity displayed by $\mathrm{L}$.

Table 1. Protonation constants of $\mathrm{L}$ determined in $0.15 \mathrm{M} \mathrm{NaCl}$ at $298.1 \pm 0.1 \mathrm{~K}$.

\begin{tabular}{ll}
\hline Reaction & $\mathrm{p} K_{\mathrm{a}}$ \\
\hline $\mathrm{H}^{+}+\mathrm{L} \leftrightharpoons[\mathrm{HL}]^{+}$ & $8.33(1)^{[\mathrm{a}]}$ \\
{$[\mathrm{HL}]^{+}+\mathrm{H}^{+} \leftrightharpoons\left[\mathrm{H}_{2} \mathrm{~L}\right]^{2+}$} & $7.06(1)$ \\
{$\left[\mathrm{H}_{2} \mathrm{~L}\right]^{2+}+\mathrm{H}^{+} \leftrightharpoons\left[\mathrm{H}_{3} \mathrm{~L}\right]^{3+}$} & $4.41(1)$ \\
{$\left[\mathrm{H}_{3} \mathrm{~L}\right]^{3+}+\mathrm{H}^{+} \leftrightharpoons\left[\mathrm{H}_{4} \mathrm{~L}\right]^{4+}$} & $3.37(1)$ \\
{$\left[\mathrm{H}_{4} \mathrm{~L}\right]^{4+}+\mathrm{H}^{+} \leftrightharpoons\left[\mathrm{H}_{5} \mathrm{~L}\right]^{5+}$} & $2.14(1)$ \\
$\log \beta$ & 25.31 \\
\hline
\end{tabular}

[a] Values in parentheses are standard deviations in the last significant figure.

The $\mathrm{pH}$-dependent absorption spectra of compound $\mathrm{L}$ are presented in Figure 1A. The two contributions from the pyridine and naphthalene chromophores can easily be detected: the pyridine shows an absorption band at around

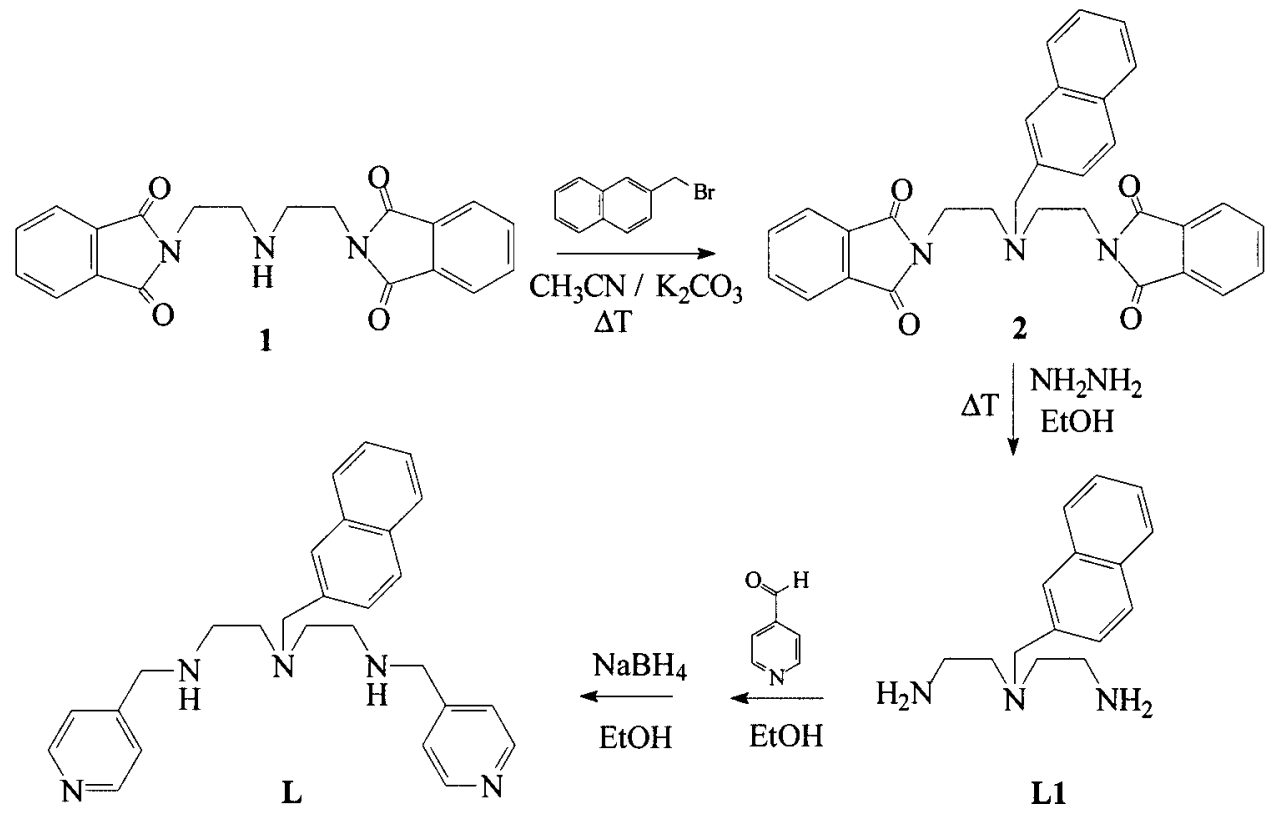

Scheme 2. Synthetic pathway to L. 
$255 \mathrm{~nm}$ whose intensity increases upon protonation, whereas the naphthalene contribution is $\mathrm{pH}$ independent and appears as a maximum at approximately $275 \mathrm{~nm}$. Observation of Figure 1A shows that there is little broadening (or extended tail) of the naphthalene absorption (above $300 \mathrm{~nm}$ ). This presumably suggests little formation (but not absence) of a pre-formed charge-transfer complex (CT complex, also commonly know as an electron donor-acceptor complex), ${ }^{[21]}$ which would result from the interaction between the electron-donating moiety (pyridine) and the electron-accepting species (naphthalene).

Fluorescence emission spectra as a function of $\mathrm{pH}$ are shown part B of Figure 1. As mentioned above, protonation of the pyridine units leads to an increase of the absorption intensity. Since there are five basic centres in L, all of them - the two secondary amino groups, the tertiary one at the centre of the chain and both pyridine nitrogens - will be protonated in $\mathrm{H}_{5} \mathrm{~L}^{5+}$. The spectroscopic data suggest that both pyridine units are also protonated in $\mathrm{H}_{4} \mathrm{~L}^{4+}$, and that even in $\mathrm{H}_{3} \mathrm{~L}^{3+}$ the proton should still interact with the pyridine units as no significant decrease in the absorption maximum is observed for the three more protonated species. The ${ }^{1} \mathrm{H}$ NMR spectroscopic data also support this average protonation sequence, since the greatest downfield shifts of the pyridine protons Py 2 and particularly Py3 (see Scheme 1 for the labelling; $\Delta \delta=0.1$ and $0.5 \mathrm{ppm}$, respectively) occur from $\mathrm{pH} 6.0$ to 4.0 , corresponding to the protonation of $\mathrm{H}_{2} \mathrm{~L}^{2+}$ to give $\mathrm{H}_{3} \mathrm{~L}^{3+}$ (see Figure $\mathrm{S} 1 \mathrm{~A}$ in the Supporting Information).

However, the most remarkable aspect to note in the emission spectra of compound L (Figure 1, B) is the additional band at longer emitting wavelengths. In fact, this emission exhibits the well-known characteristics of an exciplex as it is broad, structureless and red-shifted. The existence of a double exponential law (see below) is compatible with the existence of a "monomer" species (naphthalene emission) in equilibrium with an exciplex-like structure involving the naphthalene and one of the pyridine units. This is likely to be the case, because in a similar previously studied compound we found the coexistence of the emission of a monomer and an excimer formed by two naphthalenes. ${ }^{[22]}$ In that case the macrocyclic structure studied also possessed pyridine units, yet the maximum emission wavelength occurred at $400 \mathrm{~nm}$. This is in contrast with the $443 \mathrm{~nm}$ maximum found with the present system. It also excludes intermolecular interactions as the origin of this band. Moreover, since there is no formal difference between a relaxed CT excited state of an electron donor-acceptor complex and an exciplex, it is not easy sometimes to distinguish between the two. ${ }^{[21]}$ However, in systems where CT contributions are reported, the presence of CT band leads to a visible colour of the solutions in contrast with colourless solutions where $\mathrm{CT}$ is absent, ${ }^{[21]}$ which is reflected by the appearance of a tail at longer wavelengths. In the present case no such band is observed. Moreover, it can be seen that the absorption tail does not display a significant change with the $\mathrm{pH}$, which clearly points to a lower contribution of a CT state.
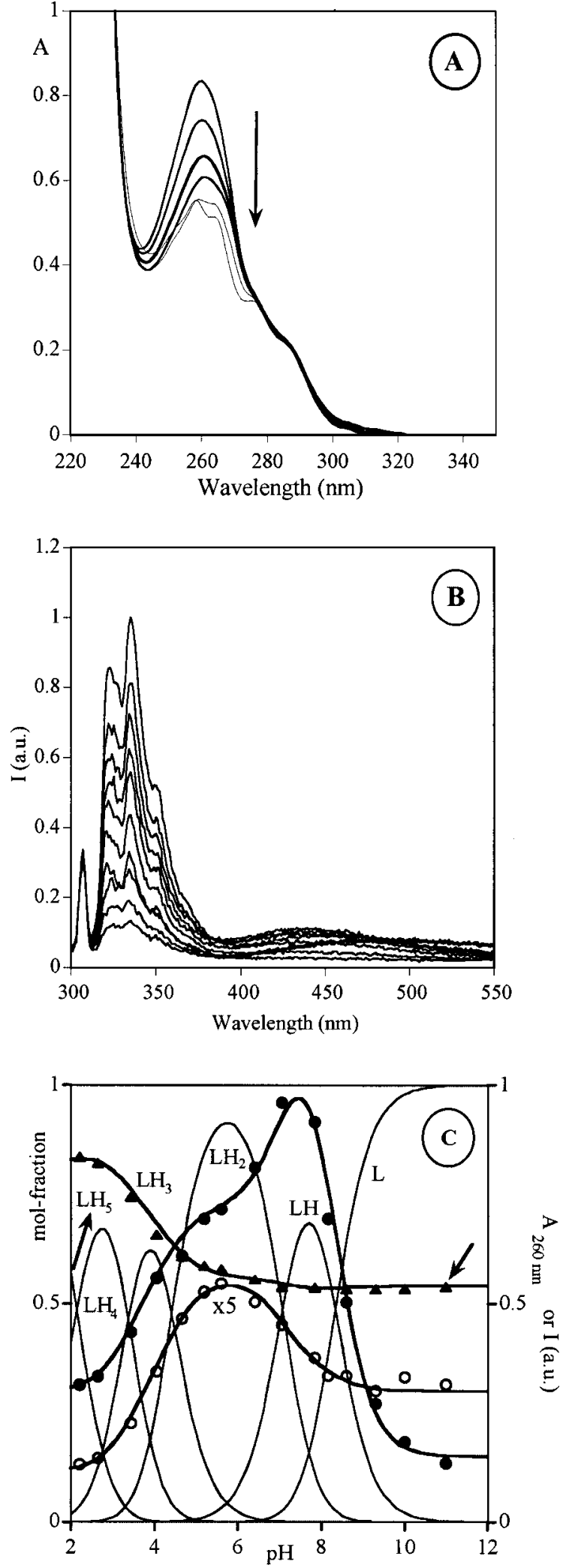

Figure 1. Absorption (A) and emission spectra (B) as function of $\mathrm{pH}$ of $\mathrm{L}\left(\lambda_{\mathrm{exc}}=280 \mathrm{~nm}\right.$ at $\mathrm{pH} 2.20,3.45,4.05,4.65,6.40$ and 11.0. $\left.[\mathrm{L}]=2.50 \times 10^{-5} \mathrm{M} ;[\mathrm{NaCl}]=0.15 \mathrm{M}\right)$. Fluorescence emission and absorption titration curves of L: emission $\left[\lambda_{\mathrm{exc}}=280 \mathrm{~nm}, \lambda_{\mathrm{em}}=\right.$ $335 \mathrm{~nm}(\bullet)$ and $\lambda_{\mathrm{em}}=443 \mathrm{~nm}(\bigcirc)$; absorption $\left.\lambda_{\mathrm{abs}}=260 \mathrm{~nm}(\boldsymbol{\Delta})\right]$ $[\mathrm{L}]=2.5 \times 10^{-5} \mathrm{M}$, superimposed on the respective mol-fraction distribution of the different species present in solution. 
The possibility of formation of a charge-transfer excited state, as observed, for instance, in dendrimers functionalised at the periphery with naphthylsulfonamide units, ${ }^{[23]}$ between the excited naphthalene and the amine units could potentially explain the emission of this structureless longemission band. However, this is not likely to explain the present situation, since a similar band is not observed with analogous compounds containing a single naphthalene unit and an amine chain. ${ }^{[24,25]}$ In fact, macrocyclic structures possessing a single naphthalene unit and polyaminic chains (with different sizes) have been shown to display only the naphthalene monomer emission. ${ }^{[24]}$ Based on the considerations above, we therefore felt confident enough to attribute the long-wavelength emission band as being due to an exciplex-type species.

Inspection of part $\mathrm{C}$ of Figure 1 shows that the decrease in the absorption (deprotonation of the pyridines) and the increase in the fluorescence emission occur simultaneously. This result can be ascribed to an electron transfer quenching from the excited naphthalene to the protonated pyridine rings. ${ }^{[1-6]}$ On the other hand, the sharp decrease of fluorescence observed at higher $\mathrm{pH}$ values can be explained by the well-established quenching by electron transfer from the lone pairs of the amines to the naphthalene fluorophore. ${ }^{[24]}$ It is interesting to note that although a higher fluorescence emission intensity should, in principle, be expected for the $\mathrm{H}_{2} \mathrm{~L}^{2+}$ species, the most emissive species is $\mathrm{HL}^{+}$. One plausible explanation could be that the two protons in $\mathrm{H}_{2} \mathrm{~L}^{2+}$, due to their mutual repulsion, should be principally located at the two terminal nitrogens. ${ }^{[20,26]}$ Therefore, the central nitrogen will be free at this stage for the quenching of the neighbouring excited naphthalene. However, the proton in $\mathrm{HL}^{+}$will be more shared between the secondary and the tertiary nitrogens due to the absence of charge-charge repulsion. The ${ }^{1} \mathrm{H}$ NMR spectroscopic data support this explanation. First, although the signal of the proton labelled as Pyb, which is placed in the $\alpha$-position with respect to the secondary amino groups, ${ }^{[9]}$ shifts downfield throughout all the $\mathrm{pH}$ range, it experiences its greatest downfield shift in the $\mathrm{pH}$ range 9-7, where the first two protonations occur $(\Delta \delta=0.3 \mathrm{ppm})$. This supports the involvement of the secondary amino groups in such protonation steps. On the other hand, the ${ }^{1} \mathrm{H}$ signal of $\mathrm{Nb}$ also undergoes a slight downfield shift $(\Delta \delta=0.12 \mathrm{ppm})$ on going from $\mathrm{pH} 9.0$ to 7.5 , corresponding to the first protonation step, which suggests that the first proton binding $\mathrm{L}$ is also shared by the tertiary nitrogen atom.

The off-on-off behaviour of $\mathrm{L}$ is depicted in Scheme 3 . This "off-on-off" behaviour of the fluorescence emission of compound $\mathrm{L}$, however, presents some disadvantages as the fluorescence emission quantum yields are very low and the $\mathrm{pH}$ width of the window is very large. A much better performance can be achieved with the $\mathrm{Zn}^{\mathrm{II}}$ complexes of compound L (see below).

The speciation studies for the system $\mathrm{Zn}^{2+}{ }_{-} \mathrm{L}$ carried out by $\mathrm{pH}$-metric titration at $298.1 \pm 0.1 \mathrm{~K}$ show a very simple model in which three species of stoichiometries $[\mathrm{ZnL}]^{2+}$, $[\mathrm{ZnL}(\mathrm{OH})]^{+}$and $[\mathrm{ZnL}(\mathrm{OH})]_{2}$ are formed. The stability con-
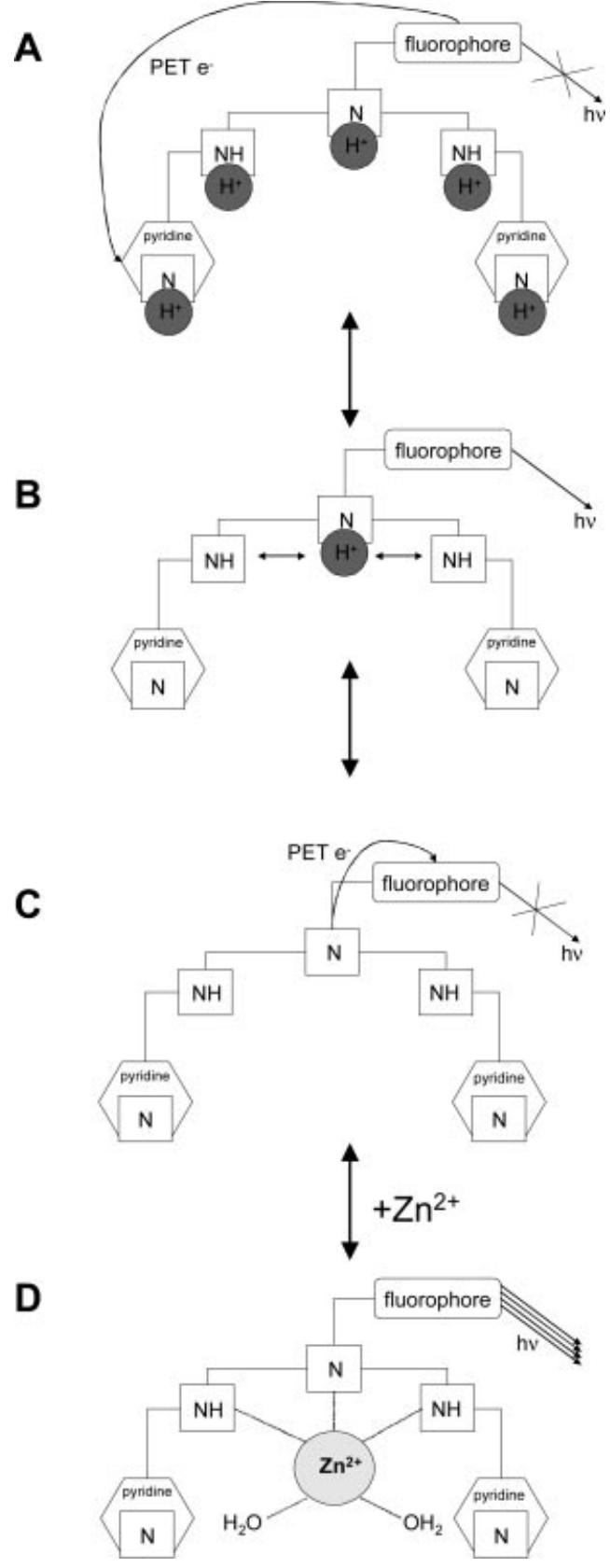

Scheme 3. Representation of the changes in fluorescence of $\mathrm{L}$ with $\mathrm{pH}$ and upon addition of $\mathrm{Zn}^{2+}$. A) Fully protonated L. B) Monoprotonated L; the proton is shared to some extent between the three nitrogens of the chain. C) Deprotonated L. D) Emission of the $[\mathrm{ZnL}]^{2+}$ complex.

stants for these species are collected in Table 2 and the distribution of the species with $\mathrm{pH}$ is shown in Figure 2.

The most noticeable observation is the low stability displayed by these complexes. The stability constant of the $[\mathrm{ZnL}]^{2+}$ complex is clearly lower than that presented by the open-chain polyamine 1,4,7-triazaheptane $(\log K=8.8)^{[18]}$ or that of a related ligand with both of its terminal nitrogens functionalised with naphthylmethyl groups $(\log K=$ 
Table 2. Stability constants for the formation of $\mathrm{Zn}^{2+}$ complexes of $\mathbf{L}$ determined in $0.15 \mathrm{M} \mathrm{NaCl}$ at $298.1 \pm 0.1 \mathrm{~K}$.

\begin{tabular}{ll}
\hline Species & $\log K^{[\mathrm{a}]}$ \\
\hline $\mathrm{Zn}^{2+}+\mathrm{L} \leftrightharpoons[\mathrm{ZnL}]^{2+}$ & $4.72(1)$ \\
$\mathrm{Zn}^{2+}+\mathrm{L}+\mathrm{H}_{2} \mathrm{O} \leftrightharpoons[\mathrm{ZnL}(\mathrm{OH})]^{+}+\mathrm{H}^{+}$ & $-4.22(2)$ \\
$\mathrm{Zn}^{2+}+\mathrm{L}+2 \mathrm{H}_{2} \mathrm{O} \leftrightharpoons\left[\mathrm{ZnL}(\mathrm{OH})_{2}\right]+2 \mathrm{H}^{+}$ & $-12.89(1)$ \\
{$[\mathrm{ZnL}]^{2+}+\mathrm{H}_{2} \mathrm{O} \leftrightharpoons\left[\mathrm{ZnL}(\mathrm{OH})_{2}\right]^{+}+\mathrm{H}^{+}$} & -8.94 \\
{$[\mathrm{ZnL}(\mathrm{OH})]^{+}+\mathrm{H}_{2} \mathrm{O} \leftrightharpoons\left[\mathrm{ZnL}(\mathrm{OH})_{2}\right]+\mathrm{H}^{+}$} & $-8.66(1)$ \\
\hline
\end{tabular}

[a] Values in parentheses are standard deviations in the last significant figure.

8.25). ${ }^{[27]}$ This low stability can be ascribed to the electronwithdrawing characteristics of the pyridine rings and to the poor $\sigma$-donor character of the central tertiary nitrogens. This low constant leads to a ready hydroxylation of two water molecules that would serve to complete the coordination sphere of the metal ion. In fact, the $\mathrm{pH}$ range of formation of the dihydroxylated species overlaps that of the monohydroxylated and of the neutral species. This low stability also means that, as might be expected, the pyridine rings do not participate in the coordination of the $\mathrm{Zn}^{2+}$ ion.

The $\mathrm{pH}$-dependent absorption and emission spectra of compound $\mathrm{L}$ in the presence of equimolar amounts of $\mathrm{Zn}^{2+}$ are shown in Figure 2. A comparison of the absorption spectra in the absence and presence of metal does not show any significant difference. However, the fluorescence emission exhibits a much higher intensity, and the shape of the fluorescence emission titration curve presents a much narrower $\mathrm{pH}$-dependent fluorescence window (Figure 2, C). The mol-fraction distribution of the various species in solution are also represented superimposed on the fluorescence emission titration curve in part $\mathrm{C}$ of Figure 2. Inspection of this figure shows the background emission from the free ligand up to $\mathrm{pH}$ 6.0, and for more basic $\mathrm{pH}$ values an emission whose shape and position can be attributed to the $[\mathrm{ZnL}]^{2+}$ species. In this species the metal is bonded to the polyamine chain, thus preventing the PET from occurring (see Scheme 3).

No interaction of the metal with the pyridine units is observed. This is confirmed by the lack of changes in the absorption spectra and absence of fluorescence quenching, which is expected when $\mathrm{Zn}^{2+}$ is bonded to pyridine units. The ${ }^{1} \mathrm{H}$ NMR signals of Py2 and Py3 in the system $\mathrm{Zn}^{2+}$ $\mathrm{L}$ do not experience any shift with respect to the free ligand from $\mathrm{pH} 2.0$ to 6.0, thus supporting this point (see Figure $\mathrm{S} 2$ ).

At higher $\mathrm{pH}$ values the formation of hydroxo species leads to a quenching effect, as reported previously, ${ }^{[28]}$ which explains the bell shape of the titration curve. One of the most remarkable aspects is the great increase in the intensity of the fluorescence emission when $\mathrm{Zn}^{2+}$ is complexed to L (see Figure 3), which exceeds the maximum intensity of the free ligand 10 -fold.

The fluorescence decays of ligand $\mathrm{L}$ were obtained at the shorter and longer wavelength bands at different $\mathrm{pH}$ values. The data resulting from the best fitting, obtained with global or independent analysis of the decays (Table 3 ) show
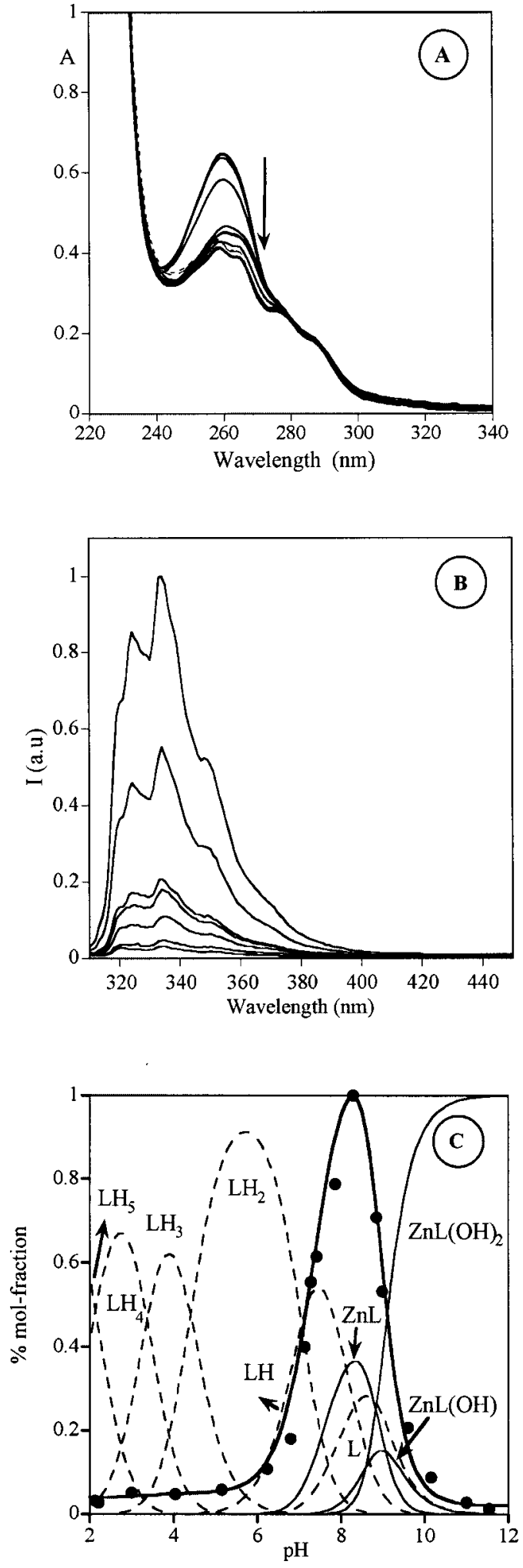

Figure 2. Absorption (A) and emission spectra (B) of the complex $\mathrm{ZnL}$ as a function of $\mathrm{pH}$. $\left(\lambda_{\mathrm{exc}}=280 \mathrm{~nm},[\mathrm{ZnL}]=2.50 \times 10^{-5} \mathrm{M}\right.$, $[\mathrm{NaCl}]=0.15 \mathrm{M})$. Fluorescence emission titration curve of the complex ZnL (C) $\left(\lambda_{\mathrm{exc}}=280 \mathrm{~nm}, \lambda_{\mathrm{em}}=335 \mathrm{~nm}(\bullet),[\mathrm{ZnL}]=\right.$ $\left.2.50 \times 10^{-5} \mathrm{M},[\mathrm{NaCl}]=0.15 \mathrm{M}\right)$ superimposed on the respective mol-fraction distribution of the different species present in solution. 


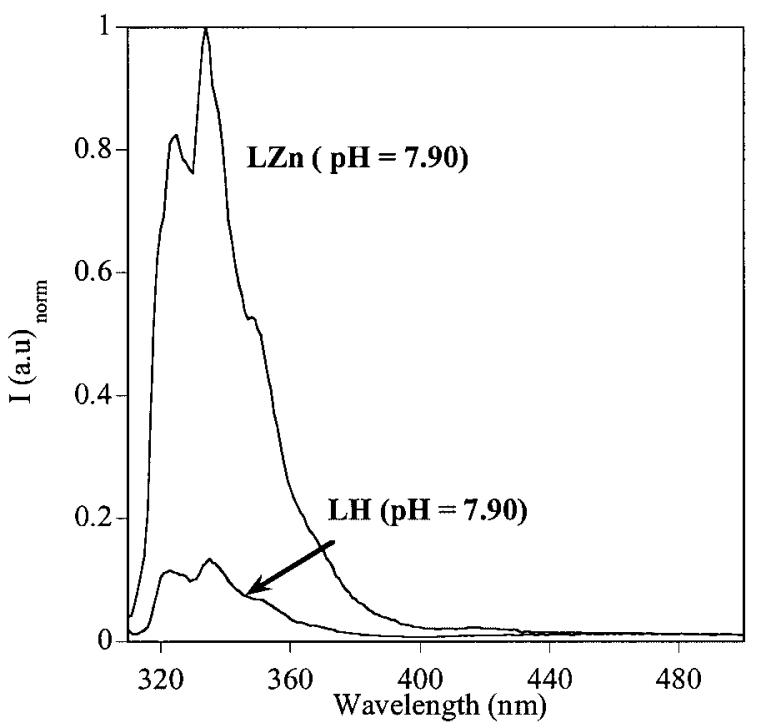

Figure 3. Comparison between the fluorescence of free $\mathrm{L}$ and its $\mathrm{Zn}^{2+}$ complex at $\mathrm{pH} 7.9$.

that the decays are properly fitted with double-exponential laws, according to:

$I_{\lambda}(t)=a_{i 1} e^{-t / \tau_{1}}+a_{i 2} e^{-t / \tau_{2}}$

where $i=1$ for $\lambda_{\mathrm{em}}=335 \mathrm{~nm}$ and $i=2$ for $\lambda_{\mathrm{em}}=450 \mathrm{~nm}$.

According to Table 3 , the shorter-lifetime component remains approximately constant with the $\mathrm{pH}$ (with an averaged value of ca. $3.4 \mathrm{~ns}$ ) and the longer-lifetime component increases up to $\mathrm{pH} 7.0-8.0$, decreasing thereafter. As reported in Figure 1, the emission at $\mathrm{pH}$ values above 8.0 is due to the deprotonated HL and L species. In this situation the lone electron pairs of the deprotonated amines are able to effectively quench the emission of compound L. ${ }^{[29]}$ This is revealed both by the decrease in the lifetime of this component as well as by the decrease of the total fluorescence emission, as shown in Figure 1, B. Analysis of the lifetime data points to another important observation: the absence of a rise-time (negative pre-exponential) is associated with the shorter lifetime at $\lambda_{\mathrm{em}}=450 \mathrm{~nm}$. The lack of a risetime (see below) might indicate that this new emission band should, presumably, possess some (small) CT degree; with improved time-resolution (ours is presently limited to $150 \mathrm{ps}$ ) it could be the case that a faster component, with a rising component, is present. However, with our current time resolution we were unable to visualize such a component. Based on our present data, this again presumably indicates that the $443 \mathrm{~nm}$ (maxima) emissive species (exciplex) results from a small CT degree contribution. In fact, exciplex formation due to CT interactions can involve excitedand ground-state molecules and be the driving force for its formation. However, based on our current data, we believe that we have a complex (presumably with some groundstate contribution) with CT character.

However, even if the formation of the exciplex-type species (emission at $443 \mathrm{~nm}$ ) does not show a strong dependence on the exciting light, it is clearly dependent on the $\mathrm{pH}$ of the medium. This can be viewed by the observation of the ratio of the emission at $335 \mathrm{~nm}$ vs. $443 \mathrm{~nm}$, where it can be seen that this attains two maxima at $\mathrm{pH} 2.0$ and pH 8.0.

In summary, the analysis of the fluorescence data (steady-state and time-resolved) suggest that the $443 \mathrm{~nm}$ emitting species can be interpreted as a charge-transfer complex $\mathrm{A}^{-} \mathrm{D}^{+}$which is stabilised by electron transfer form the donor (pyridine unit) to the acceptor (naphthalene) that is not totally unstable in its ground-state. In fact, it is unlikely, based on the arguments discussed above, that this equilibrium is only formed once the excited state is formed, but rather that it is already present (to some degree) in the ground state. Therefore, the off-on-off system is mainly due to the $\mathrm{pH}$ of the media and less to the action of light, contrary to other related systems previously studied by our groups. ${ }^{[25]}$

Table 3. Fluorescence decay times and pre-exponential factors $\left(\tau_{i}\right.$ and $\left.\mathrm{a}_{i j}\right)$ for compound $\mathrm{L}$ in water as a function of $\mathrm{pH}$. The data were obtained with excitation at $290 \mathrm{~nm}$ and emission at $335 \mathrm{~nm}$ and $440 \mathrm{~nm}$. Also presented are the chi-squared values for a better judgment of the quality of the fits.

\begin{tabular}{|c|c|c|c|c|c|c|c|}
\hline $\mathrm{pH}$ & $\lambda_{\mathrm{em}}$ & $\tau_{1}$ & $\tau_{2}$ & $a_{i 1}$ & $a_{i 2}$ & $\chi^{2}$ & Type of analysis ${ }^{[\mathrm{a}]}$ \\
\hline \multirow[t]{2}{*}{3} & 335 & 2.44 & 13.16 & 0.600 & 0.40 & 1.29 & $\mathrm{i}$ \\
\hline & 440 & 2.95 & 10.34 & 0.702 & 0.297 & 1.28 & $\mathrm{i}$ \\
\hline \multirow[t]{2}{*}{5.1} & 335 & 2.44 & 12.78 & 0.560 & 0.440 & 1.10 & $\mathrm{i}$ \\
\hline & 440 & 3.08 & 11.88 & 0.829 & 0.171 & 1.19 & $\mathrm{i}$ \\
\hline \multirow[t]{2}{*}{6.2} & 335 & 2.86 & 12.92 & 0.784 & 0.216 & 1.06 & $\mathrm{~g}$ \\
\hline & 440 & & & 0.87 & 0.13 & 1.33 & \\
\hline \multirow[t]{2}{*}{7.1} & 335 & 3.82 & 14.74 & 0.904 & 0.096 & 0.97 & $\mathrm{~g}$ \\
\hline & 440 & & & 0.897 & 0.103 & 1.06 & \\
\hline \multirow[t]{2}{*}{8.4} & 335 & 3.97 & 14.65 & 0.873 & 0.127 & 1.14 & $\mathrm{~g}$ \\
\hline & 440 & & & 0.909 & 0.091 & 1.01 & \\
\hline \multirow[t]{2}{*}{9.5} & 335 & 3.53 & 13.05 & 0.704 & 0.296 & 1.07 & $\mathrm{~g}$ \\
\hline & 440 & & & 0.882 & 0.118 & 0.83 & \\
\hline \multirow[t]{2}{*}{10.6} & 335 & 3.53 & 12.56 & 0.625 & 0.375 & 1.06 & $\mathrm{~g}$ \\
\hline & 440 & & & 0.88 & 0.12 & 1.03 & \\
\hline \multicolumn{8}{|l|}{$\mathrm{Zn}: \mathrm{L}$} \\
\hline pH 8.2 & 335 & 3.84 & 24.74 & 0.411 & 0.584 & 0.95 & 1 \\
\hline
\end{tabular}

[a] i: Independent analysis; g: global analysis. 


\section{Off-On-Off Behaviour}

According to the data reported in Figure $2(\mathrm{C}), \mathrm{Zn}^{2+}$ can be detected by the fluorescence emission intensity of its complex with tweezer $\mathrm{L}$, in a very narrow $\mathrm{pH}$ window centred at around $\mathrm{pH}$ 8.0. In order to characterise the narrowness of the bell shape titration curve, it is useful to measure the width at half of the maximum of the fluorescence intensity. In the present system it is $1.9 \mathrm{pH}$ units. This value compares with a value of about 3 for the system previously reported by A. P. de Silva. ${ }^{[1]}$ Another aspect concerns the central $\mathrm{pH}$ value of the window, which is $\mathrm{pH} 8.2$ in our system and about 6.5 in the one previously described by de Silva.

Different to previously reported systems, our system presents the advantage of being soluble and therefore operative in aqueous $0.15 \mathrm{~m} \mathrm{NaCl}$ solutions. This ionic strength is close to that found in biological fluids.

\section{Experimental Section}

The synthesis of 1 was carried out as described previously. ${ }^{[12]}$

3-Naphthylmethyl-1,5-Diphthalimido-3-azapentane $\quad(2):^{[15,16]} \quad 1,5-$ Diphthalimido-3-azapentane (1; $10.1 \mathrm{~g}, 36.2 \mathrm{mmol}), \quad$ 2-(bromomethyl)naphthalene $(10.0 \mathrm{~g}, 45.2 \mathrm{mmol})$ and $\mathrm{K}_{2} \mathrm{CO}_{3}(6.4 \mathrm{~g}$, $45.2 \mathrm{mmol}$ ) were dissolved in $200 \mathrm{~mL}$ of $\mathrm{CH}_{3} \mathrm{CN}$ and the mixture was refluxed for $24 \mathrm{~h}$ under nitrogen. After filtration, the solvent was removed under reduced pressure. The resulting residue was mixed with $50 \mathrm{~mL}$ of water and extracted with dichloromethane $(3 \times 50 \mathrm{~mL})$. The organic phase was dried with anhydrous sodium sulfate and the solvent was evaporated to yield a light-yellow oil. The oil was taken up in EtOH and precipitated as a solid, which was filtered to give 2. Yield: $6.85(38 \%) .{ }^{1} \mathrm{H} \mathrm{NMR}\left(\mathrm{CDCl}_{3}\right): \delta=$ $2.87(\mathrm{t}, J=6 \mathrm{~Hz}, 4 \mathrm{H}), 3.79(\mathrm{t}, J=6 \mathrm{~Hz}, 4 \mathrm{H}), 3.80(\mathrm{~s}, 2 \mathrm{H}), 7.16$ $(\mathrm{d}, J=8 \mathrm{~Hz}, 1 \mathrm{H}), 7.20(\mathrm{~d}, J=8 \mathrm{~Hz}, 1 \mathrm{H}), 7.23-7.36(\mathrm{~m}, 2 \mathrm{H})$, 7.45-7.48 (m, 1 H), $7.51(\mathrm{~s}, 1 \mathrm{H}), 7.58-7.61(\mathrm{~m}, 1 \mathrm{H}), 7.62-7.69(\mathrm{~m}$, $8 \mathrm{H}) \mathrm{ppm} .{ }^{13} \mathrm{C}$ NMR $\left(\mathrm{D}_{2} \mathrm{O}\right): \delta=36.2,52.2,58.8,123.3,125.7$, $126.1,127.5,127.9,128.0,128.0,132.7,132.9,133.5,134.0,136.8$, $168.5 \mathrm{ppm}$.

4-(2-Napthylmethyl)-1,4,7-triazaheptane Tris(hydrochloride) (L1-3HCl): Compound 2 (6.9 g, $13.6 \mathrm{mmol})$ and hydrazine monohydrate (13.6 g $272 \mathrm{mmol}$ ) were dissolved in $400 \mathrm{~mL}$ of EtOH and the mixture was refluxed for $1 \mathrm{~d}$ under nitrogen. The precipitate was removed by filtration and the solvent was evaporated until the sample was dry. The resulting residue was dissolved in $300 \mathrm{~mL}$ of $\mathrm{CHCl}_{3}$ and the solution was stirred for $12 \mathrm{~h}$ under nitrogen. The solution was vacuum evaporated to dryness to give the crude product. This product was dissolved in EtOH and was precipitated with aqueous $\mathrm{HCl}$ to obtain $\mathrm{L}$ as its hydrochloride salt $(1.98 \mathrm{~g}, 42 \%)$. M.p. $223-224{ }^{\circ} \mathrm{C} .{ }^{1} \mathrm{H}$ NMR $\left(\mathrm{D}_{2} \mathrm{O}\right): \delta=3.30-3.34(\mathrm{~m}, 4 \mathrm{H}), 3.35-$ 3.42 (m, $4 \mathrm{H}), 4.43$ (s, $2 \mathrm{H}), 7.49$ (d, $J=8 \mathrm{~Hz}, 1 \mathrm{H}), 7.51-7.57$ (m, $2 \mathrm{H}), 7.89-797(\mathrm{~m}, 4 \mathrm{H}) \mathrm{ppm} .{ }^{13} \mathrm{C} \mathrm{NMR}\left(\mathrm{D}_{2} \mathrm{O}\right): \delta=34.8,50.1$, 59.0, 127.4, 127.6, 127.7, 128.0, 128.2, 128.5, 129.8, 131.3, 133.2, 133.7 ppm. $\mathrm{C}_{15} \mathrm{H}_{24} \mathrm{Cl}_{3} \mathrm{~N}_{3}$ (352.8): calcd. C 51.5, H 6.9, N 11.9; found $\mathrm{C} 50.9, \mathrm{H} 7.0, \mathrm{~N} 11.8$.

1,7-Bis(4-methylpyridine)-4-(2-napthylmethyl)-1,4,7-triazaheptane Pentahydrochloride (L·5HCl): 4-Pyridinecarbaldehyde (1.28 g, $11.9 \mathrm{mmol}$ ) dissolved in $100 \mathrm{~mL}$ of $\mathrm{EtOH}$ was added to a solution of $\mathrm{L} 1$ (1.30 g, $5.96 \mathrm{mmol})$ in $\mathrm{EtOH}$. $\mathrm{NaBH}_{4}(0.56 \mathrm{~g}, 15 \mathrm{mmol})$ was then added portionwise. The mixture was stirred for $2 \mathrm{~h}$ at room temperature and the solvent was then vacuum evaporated to dryness. The residue was treated with $50 \mathrm{~mL}$ of water and extracted with $\mathrm{CH}_{2} \mathrm{Cl}_{2}(3 \times 40 \mathrm{~mL})$. The organic phase was dried with anhydrous sodium sulfate and the solvent evaporated to dryness. The resulting oil was dissolved in $\mathrm{EtOH}$ and $\mathrm{L}$ was precipitated as its pentahydrochloride salt with aqueous $\mathrm{HCl}(1.55 \mathrm{~g}, 43 \%)$. M.p. 177-178 ${ }^{\circ} \mathrm{C} .{ }^{1} \mathrm{H}$ NMR $\left(\mathrm{D}_{2} \mathrm{O}\right): \delta=2.95(\mathrm{t}, J=6 \mathrm{~Hz}, 4 \mathrm{H}), 3.15(\mathrm{t}$, $J=6 \mathrm{~Hz}, 4 \mathrm{H}), 3.73(\mathrm{~s}, 2 \mathrm{H}), 4.16(\mathrm{~s}, 4 \mathrm{H}), 7.33-7.40(\mathrm{~m}, 4 \mathrm{H})$, $7.60-7.63(\mathrm{~m}, 3 \mathrm{H}), 7.70(\mathrm{~d}, J=7 \mathrm{~Hz}, 4 \mathrm{H}), 8.52(\mathrm{~d}, J=7 \mathrm{~Hz}, 4$ H) ppm. ${ }^{13} \mathrm{C}$ NMR $\left(\mathrm{D}_{2} \mathrm{O}\right): \delta=45.1,49.4,50.4,59.3,127.9,128.1$, $128.3,129.3,129.5,133.0,133.2,133.5,142.1,151.3$ ppm. $\mathrm{C}_{27} \mathrm{H}_{40} \mathrm{Cl}_{5} \mathrm{~N}_{5} \mathrm{O}_{2}$ (644.1): calcd. C 50.5, H 6.3, N 10.9; found C 50.6, H 6.4, N 10.8.

Emf Measurements: The potentiometric titrations were carried out at $298.1 \pm 0.1 \mathrm{~K}$ with $0.15 \mathrm{M} \mathrm{NaCl}$ as the supporting electrolyte. The experimental procedure (burette, potentiometer, cell, stirrer, microcomputer, etc.) has been fully described elsewhere. ${ }^{[30]}$ The acquisition of the emf data was performed with the computer program PASAT. ${ }^{[31]}$ The reference electrode was an $\mathrm{Ag} / \mathrm{AgCl}$ electrode in saturated $\mathrm{KCl}$ solution. The glass electrode was calibrated as a hydrogen-ion concentration probe by titration of previously standardised amounts of $\mathrm{HCl}$ with $\mathrm{CO}_{2}$-free $\mathrm{NaOH}$ solutions and the equivalent point determined by Gran's method, ${ }^{[32]}$ which gives the standard potential, $E^{\circ \prime}$, and the ionic product of water $\left[\mathrm{p} K_{\mathrm{w}}=\right.$ 13.73(1)].

The computer program HYPERQUAD was used to calculate the protonation and stability constants. ${ }^{[30]}$ The $\mathrm{pH}$ range investigated was 2.5-11.0 and the concentration of the metal ions and of the ligand ranged from $1 \times 10^{-3}$ to $5 \times 10^{-3} \mathrm{M}$ with $\mathrm{M}$ :L molar ratios varying from $2: 1$ to $1: 2$ The different titration curves for each system (at least two) were treated either as a single set or as separate curves without significant variations in the values of the stability constants. Finally, the sets of data were merged together and treated simultaneously to give the final stability constants.

Spectrophotometric and Spectrofluorimetric Measurements: Absorption spectra were recorded on a Shimadzu UV-2501PC spectrophotometer and fluorescence emission on a Horiba-Jobin-Yvon SPEX Fluorolog 3.22 spectrofluorimeter at $25^{\circ} \mathrm{C}$. $\mathrm{HCl}$ and $\mathrm{NaOH}$ were used to adjust the $\mathrm{pH}$ values, which were measured on a Metrohm $713 \mathrm{pH}$ meter. All measurements were made in $0.15 \mathrm{M} \mathrm{NaCl}$.

Fluorescence decays were measured using a home-built TCSPC apparatus with an $\mathrm{N}_{2}$-filled IBH 5000 coaxial flashlamp as excitation source, Jobin-Yvon monochromators, Philips XP2020Q photomultiplier, and Canberra instruments TAC and MCA. Alternate measurements (1000 c.p.c.) of the pulse profile at $285 \mathrm{~nm}$ and the sample emission were performed until $1-2 \times 10^{4}$ counts at the maximum were reached. ${ }^{[33]}$ The fluorescence decays were analysed using the modulating functions method of Striker with automatic correction for the photomultiplier "wavelength shift". [34]

Supporting Information: As supporting information we include plots of the variations with $\mathrm{pH}$ of the ${ }^{1} \mathrm{H}$ NMR chemical shifts of protons labelled as py2, py3 (Figure $\mathrm{S} 1 \mathrm{~A}$ ), $\mathrm{Nb}$ and pyb (Figure $\mathrm{S} 1 \mathrm{~B})$. Figure $\mathrm{S} 2$ plots the variations with $\mathrm{pH}$ of the chemical shifts of protons py 2 and py 3 in the absence and presence of $\mathrm{Zn}^{2+}$.

\section{Acknowledgments}

Financial support from the Spanish Dirección General de Enseñanza Superior (projects BQ2003-0215-CO3 and GV-Grupos-03/196 and GV04B-225), the Portuguese Fundaçao para a Ciência e a Tecnologia MCT-ES (project POCTI/QUI/97357/2002 FCT-FEDER) 
is acknowledged. R. A. thanks the MECD for a PhD grant (AP2002-1382) and K. M. the Fulbright Commission for a grant.

[1] A. P. de Silva, H. Q. N. Gunaratne, C. P. McCoy, Chem. Commun. 1996, 21, 2399-2400.

[2] A. P. de Silva, H. Q. N. Gunaratne, T. T. Gunnlaugsson, A. J. M. Huxley, C. P. McCoy, J. T. Rademacher, T. E. Rice, Chem. Rev. 1997, 97, 1515-1566.

[3] A. P. de Silva, H. Q. N. Gunaratne, P. L. M. Lynch, J. Chem. Soc., Perkin Trans. 2 1995, 685-690.

[4] S. A. de Silva, A. Zavaleta, D. E. Baron, O. Allam, E. V. Isidor, N. Kashimura, J. M. Percarpio, Tetrahedron Lett. 1997, 38, 2237-2240.

[5] L. Fabbrizzi, F. Gatti, P. Pallavicini, L. Parodi, New J. Chem. 1998, 22, 1403-1407.

[6] S. A. de Silva, B. Amorelli, D. C. Isidor, K. C. Loo, K. E. Crooker, Y. E. Pena, Chem. Commun. 2002, 1360-1361.

[7] Y. V. Li, C. J. Hough, J. M. Savey, Sci. STKE 2003, 182, 19.

[8] L. Aniksztejn, G. Charton, Y. Ben-Ari, Brain Res. 1987, 404, 58-64.

[9] S. Y. Assaf, S. H. Chung, Nature 1984, 308, 734-736.

[10] G. A. Howell, M. G. Welch, C. J. Frederickson, Nature 1984, 308, 736-738.

[11] S. Peters, J. Koh, D. W. Choi, Science 1987, 236, 589-593.

[12] E. H. Buhl, T. S. Otis, I. Mody, Science 1996, 271, 369-373.

[13] Y. Li, C. J. Hough, C. J. Frederickson, J. M. Sarvey, J. Neurosci. 2001, 21, 8015-8025.

[14] P. L. Anelli, L. Lunazzi, F. Montanari, S. Quici, J. Org. Chem. 1984, 49, 4197-4203.

[15] G. H. Searle, S. F. Lincoln, S. G. Teague, D. G. Rowe, Aust. J. Chem. 1979, 32, 519.

[16] C. Yuen Ng, R. J. Motekaitis, A. E. Martell, Inorg. Chem 1979, 18, 2982-2986.

[17] P. Gans, A. Sabatini, A. Vacca, Talanta 1996, 43, 1739-1753.

[18] a) A. E. Martell, R. M. Smith, Critical Stability Constants, Plenum, New York, 1975; b) R. J. Motekaitis, NIST Critically Selected Stability Constants of Metal Complexes Database, NIST Standard Reference Database, version 4, 1997.

[19] M. A. Bernardo, J. A. Guerrero, E. García-España, J. M. Llinares, F. Pina, J. A. Ramírez, C. Soriano, J. Chem. Soc., Perkin Trans. 2 1996, 2335-2342.

[20] A. Bencini, A. Bianchi, E. García-España, M. Micheloni, J. A. Ramírez, Coord. Chem. Rev. 1999, 88, 97-156.
[21] F. Brouwer, Structural Aspects of Exciplex Formation, in Conformational Analysis of Molecules in Excited States (Ed.: J. Waluk), Wiley-VCH, New York, 2000.

[22] J. Seixas de Melo, J. Pina, F. Pina, C. Lodeiro, A. J. Parola, J. C. Lima, M. T. Albelda, M. P. Clares, E. Garcia-España, J. Phys. Chem. B 2003, 107, 11307-11318.

[23] F. Pina, M. Maestri, V. Balzani, F. Vogtle, ChemPhysChem. 2004, 5, 473-480.

[24] F. Pina, J. C. Lima, C. Lodeiro, J. Seixas de Melo, P. Díaz, M. T. Albelda, E. García-España, J. Phys. Chem. A 2002, 106, $8207-8212$.

[25] M. T. Albelda, M. A. Bernardo, P. Díaz, E. García-España, J. Seixas de Melo, F. Pina, C. Soriano, S. V. Luis, Chem. Commun. 2001, 1520-1521.

[26] J. E. Sarneski, H. L. Surprenant, F. K. Molen, C. N. Reiley, Anal. Chem. 1975, 47, 2116.

[27] J. Alarcón, R. Aucejo, M. T. Albelda, S. Alves, M. P. Clares, E. García-España, C. Lodeiro, K. L. Marchin, J. Parola, F. Pina, J. Seixas de Melo, C. Soriano, Supramol. Chem. 2004, 16, 573580

[28] a) A. Bencini, A. Bianchi, C. Lodeiro, A. Masotti, A. J. Parola, F. Pina, J. Seixas de Melo, B. Valtancolo, Chem. Commun. 2000, 1639-1640; b) C. Lodeiro, A. J. Parola, F. Pina, C. Bazzicalupi, A. Bencini, A. Bencini, C. Giorgi, A. Masotti, B. Valtancoli, Inorg. Chem. 2001, 40, 2968-2975; c) M. P. Clares, J. Aguilar, R. Aucejo, C. Lodeiro, M. T. Albelda, F. Pina, J. C. Lima, A. J. Parola, J. Pina, S. Seixas de Melo, C. Soriano, E. García-España, Inorg. Chem. 2004, 43, 6114-6122.

[29] B. Valeur, Molecular Fluorescence, Wiley-VCH, Weinheim, 2002.

[30] E. García-España, M. J. Ballester, F. Lloret, J. M. Moratal, J. Faus, A. Bianchi, J. Chem. Soc., Dalton Trans. 1988, 101-104.

[31] M. Fontanelli, M. Micheloni, Proceedings of the I Spanish-Italian Congress on Thermodynamics of the Metal Complexes, Diputación de Castellón, Castellón, Spain, 1990. Program for the automatic control of microburette and the acquisition of the electromotive force readings.

[32] a) E. Gran, Analyst (London) 1952, 77, 661; b) F. J. C. Rossotti, H. Rossotti, J. Chem. Educ 1965, 42, 375.

[33] J. Seixas de Melo, P. F. Fernandes, J. Mol. Struct. 2001, 565, 69-78.

[34] G. Striker, V. Subramaniam, C. A. M. Seidel, A. Volkmer, J. Phys. Chem. B. 1999, 103, 8612-8617.

Received: May 4, 2005 Published Online: September 8, 2005 